\title{
Editorial
}

\section{Caminhos e horizontes da RCH no campo dos periódicos acadêmicos} Ways and horizons of the RCH in the field of academic journals http://dx.doi.org/10.5007/2178-4582.2017v51n2p287

A comunicação científica em periódicos tem adquirido maior relevância no cenário mundial na medida em que o desenvolvimento tecnológico vem permitindo não só a maior divulgação, mas a coleta sistemática de dados sobre o que é produzido, sobre quem produz e como. Nesse contexto, a política de comunicação em acesso aberto enfrenta interesses de mercado e desafia agências governamentais a garantir a democratização do conhecimento.

A Revista de Ciências Humanas - RCH tem contribuído para a disseminação do conhecimento produzido no âmbito da academia desde 1982. Ao longo dessa trajetória, participou da abertura democrática do país analisando seus avanços e percalços, renovando agendas temáticas, desvelando atores sociais, projetos de submissão e controle, formas de organização, resistência e transcendência.

Criada na gestão do Prof. Paulo Lago à frente do Centro de Filosofia e Ciências Humanas e com o apoio da Editora da UFSC, a revista sempre recebeu atenção e investimentos para a qualificação de sua equipe e edições. Com o contínuo apoio da Direção do $\mathrm{CFH}$, hoje a $\mathrm{RCH}$ articula e é articulada por sete Programas de Pós-graduação que compõem sua editoria científica e que, em conjunto com um conselho editorial internacional, avaliam e avalizam seu conteúdo.

Através da manutenção de avaliações regulares e consistentes das submissões recebidas, do compromisso com a periodicidade e busca constante de atualização em relação ao cenário editorial científico mundial, a RCH vem se constituindo um veículo de crescente interesse por parte de pesquisadores e referência em termos de normalização para a construção de um perfil mais preciso da produção científica brasileira. Como resultado, as submissões e acessos às edições publicadas cresceram na ordem de $300 \%$ nos últimos quatro anos. Autores filiados a diferentes Programas de Pós-graduação no país tem colocado a $\mathrm{RCH}$ entre as 10 revistas de áreas afim onde se mais publicam conteúdos da Psicologia, por exemplo. Vale vislumbrar também seu impacto 
em outras áreas do conhecimento, dada a amplitude temática e metodológica que é capaz de abrigar.

A UFSC, reconhecendo o potencial e efetivo crescimento do periódico, tem apoiado sistematicamente a revista através de programas de extensão e estágio, excelentes oportunidades de oferecer formação à acadêmicos de todas as áreas em uma perspectiva unificadora de ensino, pesquisa e extensão. A experiência acumulada e compartilhada inclui inovações no campo das ciências da informação fundamentais para as mudanças no cenário da produção científica em nível internacional.

É mister destacar aqui o papel do Portal de Periódicos da UFSC que desde sua criação há nove anos, constituiu uma parceria inestimável no enfrentamento dos desafios que se colocam e complexificam a cada ano que passa. A equipe comprometida e qualificada tem sido uma interlocutora crítica e propositiva, generosa e atenta.

Ao completar 35 anos, sem poder comemorar, no entanto, o amadurecimento de nossa democracia que, golpeada e fragilizada, vem sucumbindo diante da perda de direitos humanos fundamentais; em um momento em que o conhecimento científico talvez mais do que nunca seja tratado como mercadoria e menos como possibilidade de solução de problemas sociais; quando as palavras de ordem no campo da difusão da ciência são "profissionalização", "sustentabilidade" e "internacionalização", unidas não ao acaso, a RCH quer se juntar ao coro que pretende discutir esses preceitos, trazendo-os para a esfera ética, em uma ampliação das "boas práticas" que contribua para nos conduzir rumo à dignidade, cooperação e compartilhamento.

Com os avanços já alcançados, o perfil da RCH se delineia cada vez mais inter, seja no campo disciplinar, no campo dos diferentes setores das políticas e da sociedade, no campo das marcações das diferenças e das formas diversas de se abordar as relações de igualdade e desigualdade entre os humanos: interdisciplinar, intersetorial e interseccional. Eis seus desafios mais emergentes. Sempre aberta ao novo e atenta à democratização do conhecimento, é no enfrentamento dos desafios que a $\mathrm{RCH}$ conquista cada vez maior e melhor visibilidade, ampliando os horizontes dos seus 35 anos de existência.

Boa leitura! 